\title{
PENGARUH MEDITASI DALAM PENDIDIKAN ISLAM UNTUK MEMPERKUAT SISTEM IMUN SEBAGAI TINDAKAN MELAWAN COVID-19
}

\author{
Sonia Sinta Salsabila \\ Universitas Ahmad Dahlan \\ soniasalsabilla62@gmail.com
}

\begin{abstract}
Meditation in Islamic education can be done by way of worship such as dhikr and prayer. To prevent covid-19, a strong immune system is needed. In an effort to improve the immune system, Islamic education meditation is one way that can help improve the immune system. The purpose of this study is to ensure that meditation in Islamic education is able to prevent the exposure of covid-19. The method used in this study is a qualitive method in the form of library research and using data sources such as journals, book, and articles. The results of this study indicate that most people feel worried and paniced, if by doing dhikr and prayer they will feel calm and not feel panic so that the immune system can increase. Meditation in Islamic education if done continuously it will increase the immune system in the body to the maximum.
\end{abstract}

Keywords: Meditation, immune system, Dhikr

\begin{abstract}
Abstrak
Meditasi dalam pendidikan Islam bisa dilakukan dengan cara beribadah seperti dzikir dan shalat. Untuk melakukan pencegahan terhadap covid-19 maka dibutuhkan sistem imun yang kuat. Sebagai upaya meningkatkan sistem imun maka meditasi pendidikan Islam adalah salah satu cara yang dapat membantu meningkatkan sistem imun tersebut. Tujuan penelitian ini adalah untuk memastikan bahwa meditasi dalam pendidikan Islam mampu mencegah terpaparnya covid-19. Metode yang digunakan dalam penelitian ini adalah metode kualitatif dengan bentuk penelitian kepustakaan dan menggunakan sumber data seperti jurnal, buku, dan artikel. Hasil penelitian ini menunjukkan bahwa sebagian besar orang merasa khawatir dan panik, jika dengan melakukan dzikir dan shalat maka mereka akan merasakan ketenangan dan tidak merasa panik sehingga sistem imun dapat meningkat. Meditasi dalam Pendidikan Islam apabila dilakukan secara terus menerus maka akan meningkatkan sistem imun dalam tubuh secara maksimal.
\end{abstract}

Kata Kunci: Meditasi, Sistem Imun, Dzikir 


\section{PENDAHULUAN}

Permasalahan yang diambil sebagai bahan penelitian ini adalah pengaruh meditasi untuk memperkuat dan meningkatkan sistem imun dalam pendidikan Islam sebagai upaya pencegahan Covid-19 atau biasa dikenal dengan sebutan virus corona. Covid-19 merupakan virus yang baru-baru ini muncul di Wuhan, China pada tanggal 31 Desember 2019. Covid-19 masih satu spesies dengan SARS dan Mers yaitu virus yang menyerang terhadap sistem pernapasan. Untuk mencegah virus corona atau Covid-19 sangat diperlukan sistem imun yang tinggi. Abbas, (2000) dan Herowitz, (1993) Imunitas merupakan sistem yang digunakan untuk perlindungan tubuh dalam melawan penyakit terutama yang disebabkan oleh virus dan berakibat infeksi. Imun kemudian melakukan sebuah reaksi guna melawan substansi asing, atau biasa disebut dengan respons imun (Julianto \& Subandi, 2015).

Sistem imun bisa meningkat apabila tidak merasa panik dan tidak stres. Dalam upaya meningkatkan sistem imun maka meditasi adalah salah satu cara yang paling mudah dilakukan. Meditasi adalah salah satu cara yang digunakan untuk merelaksasikan pikiran dari semua bentuk perasaan yang membuat seseorang merasa bahagia, merasa terbebani, dan segala macam bentuk perasaan yang lain. Ketika seseorang melakukan meditasi, yang terjadi adalah frekuensi getaran gelombang otak turun, nafas akan melambat, dan oksigen yang terpakai menjadi hemat. Selanjutnya gelombang otak akan mencapai alam bawah sadar dan gelombang otak akan mendatar dan berada pada keadaan alpha keadaan ini dinamakan keadaan homeostatis atau keadaan yang seimbang (Effendi, 2002: 14) oleh karena itu otak akan mengeluarkan hormon endorphin dan terjadilah self healing.

Meditasi biasanya berhubungan dengan kegiatan keagamaan atau spiritual, namun banyak juga meditasi yang digunakan di dalam dunia medis tanpa adanya unsur keagamaan atau spiritual. Dalam pendidikan Islam meditasi dapat dilakukan dengan cara berdzikir. (Sangkan, 2002; Aemilianus, 2012) Dzikir menimbulkan efek relaksasi ketika dipadukan dengan kalimat ritmis. Harus disertai sikap pasif baik dari luar ataupun dari dalam. Sikap pasif diibaratkan dengan sikap pasrah 
terhadap Tuhan. Sikap pasrah dapat menimbulkan respon relaksasi yang berlipat ganda serta dapat menimbulkan ketenangan. (Purwanto, 2016). Selain berdzikir, dengan melaksanakan shalat 5 waktu atau 17 rakaat dalam waktu satu hari. Melaksanakan shalat 5 waktu dalam sehari sama dengan melaksanakan aktivitas fisik dan psikis, yang di dalamnya terkandung unsur bio-energi dan konsentrasi otot, gerakan otot-otot dalam sholat merupakan proses relaksasi. Relaksasi tersebut menurut Lekrer dan Nizami dalam kutipan Arif Wibisono (1985), dapat mengurangi tingkat kecemasan, dan dapat membawa seseorang dalam situasi ekuilibrium (kesetimbangan) antara jiwa dan raga.

Tujuan penelitian ini digunakan untuk memastikan bahwa meditasi dalam pendidikan Islam ini mampu dijadikan sebagai bentuk perlawanan terhadap Covid-19 atau virus corona yang saat ini sedang mengancam Indonesia bahkan dunia.

\section{KAJIAN LITERATUR DAN PENGEMBANGAN HIPOTESIS}

Kajian literatur ini menggunakan metode kualitatif. Menurut Hamzah, (2000) penelitian kualitatif tidak membutuhkan seberapa besar responden akan tetapi untuk mendapatkan informasi yang berkualitas maka harus berfokus pada sampel kecil dalam kelompok (Hua, 2016). Dengan menggunakan bentuk penelitian kepustakaan menurut Sugiyono, (2012) metode penelitian kepustakaan (library research) merupakan penelitian yang berkaitan dengan kajian teoritis dan penelitian ini diambil dari beberapa referensi yang dikaitkan dengan literatur ilmiah (Ramanda et al., 2019). Penelitian kepustakaan ini diambil dari beberapa jurnal, artikel, dan buku. Jurnal dan buku tentang meditasi pendidikan Islam, artikel tentang covid-19, dan buku tentang meditasi. Titik permasalahan penelitian ini adalah bagaimana cara meningkatkan sistem imun sebagai tindakan melawan Covid-19. Kemudian diambil kesimpulan bahwa pengembangan hipotesis penelitian ini adalah meditasi secara teori mampu meningkatkan sistem imun dalam tubuh. 


\section{HASIL DAN PEMBAHASAN}

\section{A. Dampak Covid-19}

Beberapa bulan yang lalu tepatnya bulan Desember 2019 muncul virus baru yaitu Covid-19 atau virus corona (SARS-CoV-2) yang ditemukan di Wuhan, China dengan total 45.171 kasus pneumonia yang telah dikonfirmasi (per 12 februari 2020). Covid-19 adalah virus pathogen ketiga yang muncul setelah kurang lebih dua dekade terakhir. (Kampf et al., 2020). Pada tanggal 30 Januari 2020, di China kasus yang terkonfirmasi mencapai 7.736, dan 86 kasus yang lain tersebar dibeberapa negara di Asia, India, Srilanka, Nepal, Kanada, Finlandia, Prancis, dan Jerman. Covid-19 merambah ke Indonesia pada tanggal 2 Maret 2020 berjumlah 2 kasus. Kemudian pada tanggal 31 Maret 2020 tercatat 1.528 kasus, 136 kasus kematian. Indonesia merupakan kasus tertinggi se Asia Tenggara mencapai 8,9\%. (Susilo et al., 2020).

Penyebaran virus ini sangat cepat dan sudah melalui orang ke orang, maka dari itu sangat penting melakukan pencegahan agar tidak semakin luas penyebarannya. Covid-19 dapat bertahan hidup di permukaan kering yang terkontaminasi oleh droplet (batuk atau bersin) dari si penderita Covid-19 ini. Maka dari itu perlu ditekankan lagi untuk mengetahui tentang presistensi virus ini yang terdapat pada permukaan benda mati.(Al-Mandhari et al., 2020). Pada umumnya virus hanya dapat bertahan selama beberapa jam saja pada permukaan benda kecuali jika suhu dan kelembabannya memungkinkan, maka virus dapat bertahan selama beberapa hari. Covid-19 ternyata sensitif terhadap sinar ultraviolet dan panas. Waktu kelangsungan hidup covid-19 pada suhu lingkungan yang berbeda adalah sebagai berikut.

\begin{tabular}{|l|l|l|}
\hline Jenis Lingkungan & Suhu & Daya Bertahan \\
\hline Udara & $10 \sim 15^{\circ} \mathrm{C}$ & 4 jam \\
\cline { 2 - 3 } & $25^{\circ} \mathrm{C}$ & $2 \sim 3$ menit \\
\hline Percikan & $<25^{\circ} \mathrm{C}$ & 24 jam \\
\hline Lendir nasal & $56^{\circ} \mathrm{C}$ & 30 menit \\
\hline
\end{tabular}




\begin{tabular}{|l|l|l|}
\hline Cairan & $75^{\circ} \mathrm{C}$ & 15 menit \\
\hline Tangan & $20^{\sim} 30^{\circ} \mathrm{C}$ & $<5$ menit \\
\hline Kain non-woven & $10^{\sim} 15^{\circ} \mathrm{C}$ & $<8$ jam \\
\hline Kayu & $10^{\sim} 15^{\circ} \mathrm{C}$ & 48 jam \\
\hline Baja tahan karat & $10^{\sim} 15^{\circ} \mathrm{C}$ & 24 jam \\
\hline Alkohol 75\% & Semua suhu & $<5$ menit \\
\hline Pemutih & Semua suhu & $<5$ menit \\
\hline
\end{tabular}

(Wang Zhou, 2020)

Kesuksesan yang berkelanjutan oleh WHO dalam upaya mencegah, mendeteksi, dan mengawasi wabah Covid-19 ini tergantung solidaritas masyarakat global, terutama masyarakat Indonesia. Transparansi dan berbagi informasi positif adalah cara terbaik dalam memahami sejauh mana wabah Covid19 ini berkembang, memahami potensi penyebaran dan konsekuensi yang dihasilkan (Wilder-Smith \& Freedman, 2020).

Pada umumnya Covid-19 menginfeksi orang dewasa dan orang tua akan tetapi anak-anak dan remaja pun kemungkinan besar bisa terpapar Covid-19. Virus ini mempunyai gejala mirip dengan flu, tak jarang pada orang dewasa juga mengalami diare, mual, dan muntah. Sebagian besar Covid-19 ditularkan melalui percikan (droplet), dan menyebar melalui rute penularan kotoran melalui mulut. Masa inkubasi untuk virus corona biasanya 3 sampai 7 hari. Covid-19 adalah virus corona yang mengalami mutasi antigenik. Masa inkubasi virus paling sedikit adalah 1 hari dan tidak lebih dari 14 hari. Tetapi ada sebagian besar terdapat kasus yang dilaporkan memiliki masa inkubasi hingga 24 hari. Virus corona sangat menular dan sangat berakibat fatal, tetapi letalitasnya sampai saat ini masih belum ditentukan. Untuk saat ini, masih belum ditemukan vaksin untuk mencegah virus corona ini. Namun ada beberapa cara yang digunakan untuk melakukan pencegahan terhadap Covid-19 atau virus corona ini.

Pusat Pengendalian dan Pencegahan Penyakit AS (CDC) 24 merekomendasikan untuk menggunakan sanitasi yang baik karena dapat mengurangi risiko infeksi, sering mencuci tangan dengan sabun, menggunakan 
masker ketika keluar rumah, ketika batuk atau bersin gunakan siku atau sapu tangan untuk menutupi mulut, jangan menyentuh bagian wajah terutama mata, hidung, dan mulut jika tangan masih dalam keadaan kotor, membuat ventilasi udara dengan baik agar udara yang masuk tidak kotor dan selalu membersihkan meja, gagang pintu, atau benda-benda lain yang sering digunakan. Salah satu cara yang paling efektif untuk menghindari wabah penyakit menular seperti wabah virus corona adalah dengan melakukan karantina. Kesehatan Masyarakat di Italia melakukan karantina ketika telah melewati perjalanan dari pelabuhan kapal yang terinfeksi wabah akhirnya ketika kapal tiba di pelabuhan Venesia harus dikarantina selama 40 hari. (Xu1 et al., 2020).

\section{B. Sistem Imun sebagai Tindakan Melawan Covid-19}

Untuk melakukan pencegahan terhadap Covid-19, seseorang harus selalu menjaga sistem imun dalam tubuh agar tidak menurun. Menurut Guyton dan Hall (1996:435) Dalam tubuh manusia terdapat kemampuan untuk melakukan perlawanan terhadap organisme atau toksin yang dapat merusak sistem jaringan dan organ tubuh. Kemampuan tersebut biasa kita kenal sebagai kekebalan atau imunitas. Beberapa imunitas disebabkan oleh imun khusus yang melakukan pembentukan antibodi dan limfosit yang kemudian diaktifkan untuk melakukan penyerangan atau penghancuran terhadap toksin tertentu, Kekebalan tersebut dinamakan kekebalan buatan atau sistem imun spesifik.

Terdapat jenis imunitas tambahan yang disebebkan oleh imun umum dan bukan dari proses yang digunakan untuk melawan organisme yang dapat menyebabkan penyakit spesifik. Kekebalan tersebut dinamakan kekebalan bawaan atau sistem imun nonspesifik (Hari, 2008). Setiap kali otak bekerja, akan menghasilkan reaksi yang disebut dengan reaksi biokimia. Ada beberapa sistem kerja otak yang bereaksi lebih kuat dari yang lain, tergantung intensitas emosionalnya. Pikiran dan tubuh (biologi) memiliki hubungan yang sangat erat. Pikiran dapat menyebabkan emosi yang mengakibatkan reaksi kimia, ada beberapa reaksi yang yang menimbulkan dampak buruk dan ada juga reaksi yang bermanfaat. Ketika stress, cemas, dan marah secara terus menerus maka akan 
terjadi pelepasan cairan kimia yang terus menurus juga. Hal ini akan mempengaruhi kesehatan (Borg, 2014). Emosi negatif secara langsung dapat menyebabkan kerusakan pada pelepasan cairan kimia. Bahaya yang selanjutnya akan ditimbulkan adalah cairan tersebut akan berdampak pada sistem imunitas tubuh.

Baratawijaya, (1991) Karateristik sistem imun adalah mampu mengetahui pathogen atau sesuatu/benda asing yang kemudian masuk ke tubuh. Ketika pathogen pertama kali masuk ke dalam tubuh maka akan merasakan kepekaan dari sel-sel imun, Sehingga ketika tubuh kembali terkena pathogen yang serupa, maka tubuh sudah bisa mengenali kemudian pathogen akan dihancurkan oleh sistem imun tersebut (Sukendra, 2015). (Hooper et al., 2012) Paradigma baru mengatakan bahwa sistem kekebalan tubuh berkembang untuk melakukan akomodasi kolonisasi dari mikrobiota simbiosis yang akan bertambah kompleks akan tetapi tetap memperkuat kapasitas dalam melakukan perlawanan terhadap patogen. Sebagaimana koloni bakteri yang berasal dari usus akan mempengaruhi perkembangan fungsi sistem imun yang akan dijadikan pusat pembelajaran menarik (Hasibuan \& Kolondam, 2017). Pada saat kondisi seperti ini seseorang dianjurkan untuk tidak merasa panik dan stres agar sistem kekebalan tubuh tetap stabil dan tidak menurun.

\section{Meditasi sebagai Upaya Meningkatkan Sistem Imun}

Dalam rangka meningkatkan pemenuhan kebutuhan sistem imun dalam tubuh dan pencegahan terjadinya stres dalam upaya pencegahan Covid-19 dapat dilakukan dengan cara relaksasi meditasi. Meditasi secara umum dapat diartikan sebagai pemikiran atau perenungan (contemplation) dan refleksi (reflection). Prof. Muhammad Shafi'i (dalam Sulaiman, 2015) mendefinisikan meditasi merupakan kondisi psikofisiologis dimana seseorang mengalami keadaan pasif tetapi aktif dan diam tetapi kreatif. Oleh karena itu seseorang yang melakukan meditasi akan mendapatkan titik dimana perasaan menjadi tenang dan nyaman. 
Linda O'Riordan (Sulaiman, 2015) menjabarkan bahwa kemungkinan seseorang ketika sedang melakukan meditasi adalah ketika batin melakukan sesuatu yang dapat merefleksikan diri dan belajar menentukan untuk apa tujuan dan misi hidup sebenarnya. Cara yang dilakukan adalah belajar mengontrol tubuh, mental, dan emosional untuk menemukan jati diri kita. Membiarkan pikiran untuk mendengar dan menyerap semua energi positif dan belajar untuk menjadi pendiam akan membuahkan hasil yang memuaskan. Hal itu dapat disimpulkan dengan jelas bahwa, seseorang yang melakukan meditasi akan terbawa kedalam kesadaran untuk melakukan sesuatu di luar batasanya yang biasa dilakukan dalam kehidupan sehari-hari. Oleh karena itu seseorang akan lebih menyadari apa sebenarnya arti kehidupan dan membantu mengarahkan kondisi mental dan emosionalnya kepada hal-hal yang positif. Sehingga seseorang akan mempunyai aturan hidup yang lebih tertata karena sudah memahami konsep untuk menjalani hidup ini.

Menurut Suryani (2000), melakukan latihan relaksasi meditasi juga menurunkan tekanan darah tinggi. Relaksasi mengakibatkan obat hipertensi menjadi efektif jika melakukan pengobatan farmakologis (Sudiarto, 2007). (Kristeller \& Hallett, 1999) Meditasi hakikatnya mempertahankan kesadaran kepada satu objek yang terfokus untuk selalu menjaga sopan santun, tidak main hakim sendiri, dan menghargai diri sendiri. (Fendina et al., 2018). Menurut Subandi, (2002) meditasi merupakan aktivitas yang berfungsi menjaga perhatian pada satu objek sehingga dapat menjernihkan dan menenangkan pikiran dengan konsep religi (Dewi et al., 2018). Kozier, (2010) Relaksasi meditasi mengakibatkan tekanan darah menurun dan mempunyai prinsip tubuh menjadi tenang, pada kondisi tersebut akan mengalami keseimbangan, Oleh karena itu relaksasi meditasi yang bertumpu pada pernafasan akan mengalami kondisi rileks, dan seluruh sistem tubuh bekerja dengan baik kondisi ini menyebabkan penyesuaian terhadap hipotalamus dan aktivitas sistem saraf simpatis akan menurun sehingga aktivitas sistem parasimpatis meningkat. (Purnika et al., 2019).

Menurut Brealey (2002) yang dikutip oleh Hoiron, menyatakan bahwa pada dasarnya terapi meditasi merupakan salah satu teknik terapi yang dapat mempengaruhi tubuh agar dapat berespon positif dan membuat tubuh menjadi 
lebih tenang dan rileks. Serta bermanfaat untuk perbaikan kesehatan, baik mental maupun fisik. Ketika relaksasi pikiran akan terpusat sehingga pembuluh darah menjadi lebih elastis dari sebelumnya. Pada kondisi tersebut sirkulasi darah lebih lancar sehingga dapat merilekskan dan menghangatkan tubuh, maka kerja jantung akan semakin ringan dan sangat berpengaruh terhadap sistem kerja organ tubuh yang lain. Handoyo, (2004) relaksasi sama halnya dengan meditasi penenangan nafas yang terkonsentrasi pada kebugaran jasmani.

Pencapaiaan relaksasi meliputi ketenangan pikiran, perasaan, kejiwaan, mental dan fisik. Relaksasi olah nafas memusatkan konsentrasi irama pernafasan yang teratur, dinamis, dan harmonis (Widodo \& Purwaningsih, 2013). Lichstein, (1993) Ketika seseorang melakukan relaksasi pada saat ia sedang mengalami ketegangan atau kecemasan, maka reaksi fisiologis yang dirasakan oleh orang tersebut akan berkurang. Sehingga hanya perasaan rileks yang dirasakan. Ketika kondisi fisiknya rileks, maka psikisnya juga merasa tenang (Purwanto, 2006). Dorbyk, (2007); Glickman, (2007); Vitahealth, (2006) Meditasi adalah suatu kondisi rileks yang terjadi pada kejadian yang sedang berlangsung, atau suatu kondisi rileks dimana terbebas dari segala macam pikiran, atau terbebas dari semua kejadian yang melelahkan dan hanya terfokus kepada Tuhan, atau sedang berada pada konsentrasi yang tinggi. Meditasi akan menjadikan otak tenang dan dapat memulihkan kondisi tubuh, apabila meditasi dilakukan dengan baik dan teratur maka dapat menurunkan stres (Widodo \& Purwaningsih, 2013).

Atwater, (1999) Meditasi musik juga bisa digunakan sebagai alternatif lainnya. Musik meta dapat menghadirkan situasi seperti desis atau angin, dan juga suara pecahan ombak, selain dengan binaural beat (Prabowo, 2007). Werner, (1977) Yoga juga masuk dalam kategori kegiatan meditasi. Dalam aspek psikologi, Yoga merupakan kaidah alam spiritual yang dilakukan manusia untuk melepaskan diri dari perasaan sepi atau sendiri, sehingga merasa dekat dengan Tuhan dan tidak merasa sendiri. Hartono, (2007) Terdapat beberapa cara yang dilakukan untuk mengatasi atau mencegah stress, yang paling utama adalah banyak minum air putih, makan makanan yang bergizi, istirahat yang cukup, dan yang terakhir adalah melakukan relaksasi meditasi (Sutioningsih et al., 2019). 
(Nasir \& Mamat, 2019). Bastis, (2000) Melakukan meditasi dengan teratur mampu mengubah seseorang menjadi lebih tenang. Seseorang dapat mengatasi gangguan-gangguan emosi dengan tidak melukai dirinya sendiri atau melukai orang lain yang ada di sekitar. Meditasi mampu menenangkan pikiran dan menjadikan seseorang berpikir jernih, dimana seseorang dapat merasakan hubungan dengan setiap orang dengan berbagai macam sesuatu yang ada (Bagaskara et al., n.d.).

\section{Meditasi dalam Pendidikan Agama Islam}

Menurut (Zakiyah Darajat, 2001, h. 86) membentuk manusia yang beriman dan bertaqwa kepada Allah SWT, berakhlak mulia serta berbudi pekerti luhur, memiliki ilmu pengetahuan yang luas, merupakan beberapa fungsi dari Pendidikan Agama Islam. Agama memiliki fungsi yang sangat besar yaitu sebagai pengendalian terhadap kepribadian hidup. Sehingga, pendidikan agama harus diajarkan sejak dini karena akan terbiasa dan terlatih untuk melakukan ibadah dan menjalankan syari'at Islam dengan benar dan dengan kesadaran sendiri, tanpa disuruh (Trinova, 2013).

An-Nahlawi (1996:41) Pendidikan Islam adalah peraturan yang dilakukan secara individual dan sosial yang menjadikan seseorang patuh dan taat terhadap Islam kemudian menerapkan dengan sempurna dalam kehidupan. Pendidikan Islam adalah pendidikan yang mutlak dalam pelaksanaan agama Islam sebagaimana agama yang diridhai Allah (Ainissyifa, 2014). Pusat Kurikulum Depdiknas, (2004) Pendidikan Agama Islam yang dikatakan oleh Puskur merupakan kesadaran yang terencana dalam mempersiapkan peserta didik dalam mengenal, memahami, mengimani, dan menjalankan ajaran agama Islam yang bersumber pada Al-Qur'an dan Hadits dengan melalui bimbingan, latihan, dan pengamalan. Akan tetapi harus dibarengi dengan menghormati penganut ajaran agama lain dalam hubungan untuk mencapai kerukunan antar umat beragama di dalam lingkungan masyarakat sehingga kesatuan dan persatuan bangsa akan terwujud (Amin, 2015). 
Dengan melaksanakan pengamalan Pendidikan Agama Islam, maka cara melakukan meditasi dalam Islam adalah dengan berdzikir maupun dengan menjalankan shalat. Islam dikatakan sebagai instansi agama mempunyai beberapa keutamaan yang dapat dikaji dan diamati secara psikologi. Banyak fenomena ritual islam yang belum dikaji, seperti ritual dzikir yang terdapat beberapa aspek yang dapat diteliti misalnya aspek meditasi, relaksasi, pengalaman trasendental, yang berkaitan dengan menurunnya gangguan mental dan menimbulkan energi positif seperti ketenangan dan emosi yang stabil. Selain mendapatkan manfaat dari relaksasi tersebut, ternyata ada juga keuntungan yang dapat diambil dari relaksasi religi ini seperti mempertebal keimanan dan memungkinkan juga untuk mendapat pengalaman transendensi. Dalam hal ini dzikir yang dimaksud adalah dzikir yang mengingat akan dzat, sifat, dan perbuatan Allah yang kemudian hanya kepada Allah hidup dan mati akan dipasrahkan.

Batuqayan et al., (2012) Metode dzikir menjadikan pikiran menjadi jernih dan dapat mengembalikan pikiran menjadi netral. Melakukan dzikir dengan penghayatan akan menjadikan seseorang berada dalam ketenangan dan kenyamanan. Pada saat fisiologis tubuh dalam keseimbangan, maka keseimbangan dapat melancarkan aliran darah dan menjadikan pergerakan sel di dalam tubuh relatif stabil. Terjadinya respons keseimbangan mampu menjadikan sistem dalam tubuh berjalan dengan normal serta dapat menyehatkan badan. Subyek penelitian dengan menggunakan dzikir secara terus menerus, akan menjadikan subyek penelitian semakin mudah dan terbiasa untuk mempertahankan keseimbangan tersebut. Melakukan penguatan kopling merupakan cara yang sangat efektif untuk mengatasi stres (Utami, 2017). Pelatihan spiritual dengan menggunakan teknik meditasi terbukti dapat menurunkan stres.

Dzikir merupakan kegiatan mengingat Allah yang dilakukan oleh sebagian besar umat Islam. Dzikir juga dikatakan sebagai dasar dari seluruh ritual dalam beribadah, bahkan dzikir juga disebut sebagai ruh dari semua ibadah. Dzikir merupakan ibadah yang fleksibel dalam artian dapat dilakukan dalam keadaan 
apapun, kapanpun, dan dimanapun kita berada. Persamaan dzikir dengan meditasi atau relaksasi terdapat pada sikap pasrah. Sikap tersebut adalah sikap yang sudah pasti dibutuhkan dalam teknik relaksasi. Meditasi dzikir mampu mengendalikan hormon epinefrin dan norepinefrin yang disebabkan oleh medulla adrenal. Hal tersebut dapat memperlambat pembentukan angiotensin akibat denyut jantung yang mengalami penurunan, pelebaran pembuluh darah, berkurangnya tahanan pembuluh darah, dan penurunan pompa jantung sehingga menyebabkan penurunan pada arteri jantung yang dapat menurunkan tekanan darah. Meditasi tersebut menyebabkan kondisi menjadi lebih rileks dimana seluruh sistem tubuh bekerja dengan baik dan pada saat kondisi tersebut terjadi, hipotalamus akan menyesuaikan, akan terjadi penurunan aktivitas sistem saraf simpatis, serta meningkatkan aktivitas sistem parasimpatis.

Urutan efek fisiologis, gejala, ataupun tandanya akan terputus dan stres psikologipun menjadi berkurang. (Fadli, Resky, \& Sastria, 2019) Terapi dzikir juga dapat mempengaruhi intensitas nyeri pada pasien gastrtitis karena dalam terapi dzikir dilakukan selama 15-20 menit dan dilaksanakan 5-6 jam sebelum pasien diberikan tindakan farmakologi. (Purnika et al., 2019). Pengendalian fisik yang dilakukan dengan sengaja dalam pelaksanaan dzikir yang digabungkan dengan sikap pasrah sangat diperlukan dalam proses relaksasi. Respon relaksasi dalam sikap pasrah ini tidak hanya terjadi pada tingkatan fisik akan tetapi yang lebih mendalam adalah pada tingkatan psikis. Sikap pasrah merupakan sikap menyerahkan diri secara utuh atau totalitas seperti membaca bacaan ketika shalat “innaa sholati wanusuki wamahyaaya wamamaati lillahirobbil'aalaamiin” yang artinya sesungguhnya shalatku, ibadahku, hidupku, dan matiku hanyalah untuk Allah, Tuhan semesta alam. Sikap itulah yang disebut sikap pasrah karena menimbulkan sikap menerima sehingga segala ketegangan permasalahan hidup dapat diatasi dengan sikap pasrah ini. Ketika pengendalian fisik dalam relaksasi sudah dilakukan, maka langkah berikutnya adalah mengucapkan "yaa Allah" dengan diikuti sikap pasrah atau berserah diri dengan totalitas baik tubuh, pikiran, perasaan, serta jiwa. 
Dalam pelatihan relaksasi tidak ada batasan waktu, akan tetapi ada yang bependapat bahwa waktu terbaik dalam pelaksanaan relaksasi adalah sebelum makan atau ketika perut masih dalam keadaan kosong sehingga proses relaksasi tidak terganggu oleh kerja sistem pencernaan. Apabila pendapat tersebut digabungkan dengan kegiatan spiritual keagamaan (Islam) waktu terbaik dalam pelaksanaan relaksasi adalah setelah shalat subuh dan shalat maghrib. Untuk itu diharapkan latihan rutin 2 kali sehari ini dapat memunculkan respon relaksasi setiap saat dan sesuai kebutuhan. Sayyid Qutbh dalam (Tafsir Fi Zhilalil Qur'an jilid 1:171) Dengan melakukan shalat maka akan memunculkan kesabaran yang akan tetap ada dan tidak akan terputus. Selain mempertebal keimanan dan kesabaran, shalat juga menjadikan seorang muslim lebih ridha, tenang, teguh, dan yakin (Suparman, 2015). M. A. Hidayat, (2017) Saleh ritual merupakan ketekunan seseorang yang merujuk pada inti ibadah (hablumminallah) seperti melakukan shalat dan puasa, melaksanakan zakat, dan ziarah (Suyadi et al., 2019).

Dari uraian diatas diharapkan seseorang dapat mengetahui teknik dzikir dengan penggabungan relaksasi atau meditasi, sehingga manfaat dari respon relaksasi yang timbul akan lebih dirasakan dan dimanfaatkan. Dzikir merupakan kegiatan spiritual yang tidak hanya menyebutkan asma Allah baik secara lisan, pikiran, maupun di dalam hati.

\section{KESIMPULAN}

Berdasarkan penelitian ini dapat disimpulkan bahwa Covid-19 adalah virus baru yang sangat berbahaya serta penyakit dengan tingkat penularan yang sangat cepat. Oleh karena itu agar tidak banyak masyarakat yang terpapar virus ini, pemerintah mengeluarkan peraturan "social distancing” sehingga untuk melakukan semua kegiatan, masyarakat dianjurkan untuk tetap di rumah saja. Karena seluruh aktivitas sekolah, kampus, bahkan perusahaan pun diliburkan, maka seluruh kegiatannya dilakukan dengan daring (dalam jaringan) atau sistem online. Untuk mencegah agar tidak terpapar virus corona atau Covid-19, sangat dianjurkan untuk menjaga kebersihan dan kesehatan lingkungan, serta tetap 
menjaga sistem imun agar tidak menurun. Karena jika sistem imun menurun maka tubuh akan lebih mudah terkena virus. Dalam rangka meningkatkan sistem imun maka dapat dilakukan cara yaitu meditasi atau relaksasi agar pikiran selalu positif sehingga mengakibatkan organ tubuh menjadi rileks.

Dalam Pendidikan Agama Islam meditasi dilakukan dengan cara berdzikir dan shalat, sama halnya dengan meditasi, dzikir dan shalat juga dapat mengalirkan energi positif bagi yang melakukannya sehingga dapat meningkatkan sistem imun didalam tubuh. Di dalam literatur psikologi, Smith (1975) mengatakan bahwa meditasi merupakan acuan dari sekelompok latihan yang digunakan untuk membatasi pikiran dan perhatian.

\section{REFERENSI}

Ainissyifa, H. (2014). Pendidikan Karakter dalam Perspektif Pendidikan Islam. Jurnal Pendidikan, 8(1), 1-26.

Al-Mandhari, A., Samhouri, D., Abubakar, A., \& Brennan, and R. (2020). Coronavirus Disease 2019 outbreak: preparedness and readiness of countries in the Eastern Mediterranean Region.

Amin, A. (2015). Metode Pembelajaran Agama islam.

Bagaskara, A., Soetjipto, H. P., \& Atamimi, N. (n.d.). Kecerdasan Emosi Ditinjau dari Keikutsertaan dalam Program Meditasi. Jurnal Psikologi, 35(2), 101105.

Dewi, A., Setiawan, D., \& Yuliandi, R. (2018). Pengaruh Meditasi dalam Meningkatkan Akurasi Tendangan pada Atlet Pencak Silat di Organisasi PSHT Kabupaten Banyuwangi. Jurnal Kejaora, 3(1).

Fendina, F., Nashori, F., \& Sulistyarini, I. (2018). Efektivitas pelatihan meditasi pernafasan dalam menurunkan stress pada pendukung sebaya ODHA. Psikologi Integratif, 6(1), 1-17.

Hari, Y. (2008). Latihan Fisik dan Kekebalan Tubuh. Medikora, IV , 47-65.

Hasibuan, F. E. B., \& Kolondam, B. J. (2017). Interaction Between Gut Microbiota and the Human Immune System. Jurnal IImiah Sains, 17(1), 35-42.

Hua, A. K. (2016). Pengenalan Rangka Kerja Metodologi dalam Kajian Penyelidikan. Jurnal Social Science and Humanities, 1(1), 17-23. 
Julianto, V., \& Subandi. (2015). Membaca Al-fatihah Reflektif Intuitif Untuk Menurunkan Depresi dan Meningkatkan Imunitas. Jurnal Psikologi, 42(1), 34-36.

Kampf, G., Todt, D., Pfaender, S., \& Steinmann, E. (2020). Persistence of coronaviruses on inanimate surfaces and their inactivation with biocidal agents. Hospital Infection.

Nasir, K., \& Mamat, S. (2019). Kajian Perbandingan Antara Tradisi Meditasi Hindu di Dalam Proses Psikoterapi Al-Tafakkur Concept According to Al- Sunna: Comparison Study Between Hindu Meditation Tradition in Psychotherapy. Hadis, 9(18), 195-212.

Prabowo, H. (2007). Beberapa Manfaat Meditasi dan Altered State Consciousness. In Jurnal Penelitian Psikologi (Vol. 12, Issue 2, pp. 97-108).

Purnika, R., Roesmono, B., \& Kassaming. (2019). Pengaruh Meditasi Dzikir Terhadap Perubahan Tekanan Darah pada Pasien Hipertensi. IImiah Kesehatan Diagnosis, 14(4).

Purwanto, S. (2006). Relaksasi Dzikir. Suhuf, 18(01), 39-48.

Purwanto, S. (2016). Hubungan Antara Intensitas Menjalankan Dzikir Nafas dengan Latensi Tidur. Indigenous, 1(1), 32-38.

Ramanda, R., Akbar, Z., \& Wirasti, R. A. M. K. (2019). Studi Kepustakaan Mengenai Landasan Teori Body Image Bagi Perkembangan Remaja. Jurnal Edukasi, 5(2), 121-135.

Sudiarto, D. (2007). Pengaruh Terapi Relaksasi Meditasi Terhadap Penurunan Tekanan Darah Pada Lansia Dengan Hipertensi Di Wilayah Binaan Rumah Sakit Emanuel Klampok Banjarnegara. Soedirman Journal of Nursing, 2(3), 118-126.

Sukendra, D. M. (2015). Efek Olahraga Ringan pada Fungsi Imunitas terhadap Mikroba Patogen: Infeksi Virus Dengue. Jurnal Media IImu Keolahragaan Indonesia, 5(2).

Sulaiman, S. H. (2015). Penyembuhan Penyakit Lahiriah dan Batiniah Cara Sufi.

Suparman, D. (2015). Pembelajaran Ibadah Shalat dalam Perpektif Psikis dan Medis. 9(2).

Susilo, A., Rumende, C. M., Pitoyo, C. W., Santoso, W. D., Yulianti, M., Sinto, R., Singh, G., Nainggolan, L., Nelwan, E. J., Khie, L., Widhani, A., Wijaya, E., Wicaksana, B., Maksum, M., Annisa, F., Jasirwan, O. M., Yunihastuti, E., Penanganan, T., New, I., ... Cipto, R. (2020). Coronavirus Disease 2019 : Tinjauan Literatur Terkini Coronavirus Disease 2019: Review of Current Literatures. Jurnal Penyakit Dalam Indonesia, 7(1), 45-67. 
Sutioningsih, S., Suniawati, S., \& Suhuda, H. (2019). Pengaruh Terapi Meditasi ( Dzikir ) terhadap Tingkat Stres pada Lansia. Jurnal Keperawatan Profesional (JKP), 7.

Suyadi, Sumaryati, Hastuti, D., Yusmaliana, D., \& MZ, R. D. R. (2019). Constitutional Piety: The Integration of Anti-Corruption Education into Islamic Religious Learning Based on Neuroscience. Jurnal Pendidikan Agama Islam, 6(1). https://doi.org/10.18860/jpai.v6i1.8307

Trinova, Z. (2013). Pembelajaran Berbasis Student-Centered Learning Pada Materi Pendidikan Agama Islam. AL-Ta Lim, 20(1), 324. https://doi.org/10.15548/jt.v20i1.28

Utami, T. niswati. (2017). Tinjauan Literatur Mekanisme Zikir Terhadap Kesehatan Respons Imunitas. Jurnal Jumantik, 2(1).

Wang Zhou, M. (2020). The Coronavirus Prevention Handbook 101 science-based tips that could save your life.

Widodo, G. G., \& Purwaningsih, P. (2013). Pengaruh Meditasi Terhadap Kualitas Hidup Lansia Yang Menderita Hipertensi di Unit Rehabilitasi Sosial Wening Wardoyo Ungaran Kabupaten Semarang. Jurnal Keperawatan Medikal Bedah, 1(2).

Wilder-Smith, A., \& Freedman, D. O. (2020). Isolation, quarantine, social distancing and community containment: pivotal role for old-style public health measures in the novel coronavirus (2019-nCoV) outbreak. Journal of Travel Medicine, 1-4.

Xu1, C., Luo2, X., Yu3, C., \& Cao, S.-J. (2020). The 2019-nCoV epidemic control strategies and future challenges of building healthy smart cities. 